\title{
KOMPENSASI, MOTIVASI, PELATIHAN, DAN LINGKUNGAN KERJA PADA KUALITAS KINERJA PEGAWAI
}

\author{
Yuli Tri Cahyono ${ }^{1)}$, Eskasari Putri ${ }^{2)}$ \\ 1,2) Program Studi Akuntansi, Fakultas Ekonomi dan Bisnis, \\ Universitas Muhammadiyah Surakarta \\ Email: ${ }^{1)}$ ytc115@ums.ac.id ${ }^{2)}$ ep122@ums.ac.id
}

\begin{abstract}
Abstrak
Penelitian ini bertujuan untuk menguji dan menganalisis pengaruh kompensasi, motivasi, pelatihan, dan lingkungan kerja pada kualitas kinerja pegawai. Pengumpulan data dilakukan melalui penyebaran kuesioner. Analisis data pada penelitian ini menggunakan bantuan SPSS. Metode analisis yang digunakan adalah regresi liner berganda untuk menguji dan membuktikan hipotesis penelitian. Hasil analisis menunjukkan bahwa pelatihan berpenaruh terhadap kualitas kinerja pegawai, sedangkan kompensasi, motivasi, dan lingkungan kerja tidak berpengaruh.
\end{abstract}

Kata Kunci: pelatihan, lingkungan kerja, motivasi, kinerja pegawai

\begin{abstract}
This study aims to examine and analyze the effect of compensation, motivation, training, and work environment on the quality of employee performance. Data collection was carried out through questionnaires. Analysis of the data in this study using SPSS. The analytical method used is multiple linear regression to test and prove the research hypothesis. The results of the analysis show that training affects the quality of employee performance, while compensation, motivation, and work environment have no effect.
\end{abstract}

Keywords: training, work environment, motivation, employee performance

\section{PENDAHULUAN}

SDM merupakan aset perusahaan yang paling mahal dibanding dengan aset-aset lain, karena merupakan penggerak utama organisasi perusahaan. SDM harus dikelola secara optimal, continue, dan diberi ekstra perhatian serta memenuhi hak-haknya. Selain itu SDM adalah partner pengusaha untuk mencapai tujuan organisasi. SDM juga harus senantiasa meningkatkan kompetensinya seiring dengan perkembangan era globalisasi (Ambarita, 2012:5-8). Agar dapat bersaing dalam bisnis, perusahaan dituntut untuk memperoleh, mengembangkan, dan mempertahankan SDM yang berkualitas. SDM sebagai penggerak organisasi banyak dipengaruhi oleh pelaku pesertanya serta fungsinya sangat mendukung keberhasilan organisasi. Untuk mewujudkan tujuan organisasi diperlukan SDM yang mampu menunjang tercapainya organisasi yang baik.

Pemerintah merupakan salah satu sektor publik dalam organisasi yang memiliki dua orang atau lebih yang berinteraksi dan saling bergantungan bergabung untuk mencapai tujuan organisasi. SDM dalam organisasi pemerintah sering disebut Aparatur Sipil Negara (ASN). ASN dituntut agar mengeluarkan tenaga, pikiran, bakat, dan kreativitasnya untuk mewujudkan tujuan organisasi.

Dinas Pendapatan Pengelolaan Keuangan dan Aset Daerah (DPPKAD) adalah sebuah unit organisasi yang merupakan hasil perubahan dari BPKD (Badan Pengelola Keuangan Daerah). Unit DPPKAD ini berasal dari penyatuan tiga bidang unit kerja, yaitu Dinas Pendapatan, Bagian Kas Daerah Setda, dan Bagian Keuangan Setda. Tugas dari BPPKAD 
adalah melaksanakan fungsi administrasi untuk internal yang dulunya dilaksanakan oleh Tata Usaha. Selain itu, DPPKAD juga memiliki fungsi sebagai konsolidator dalam Bidang Pendapatan, Bendahara Umum Daerah, Anggaran, Aset, dan Akuntansi termasuk dalam pengelolaan gaji PNS. DPPKAD juga masih memiliki fungsi khusus lain dengan resiko pekerjaan serta beban yang lebih berat, yaitu pengelolaan dana hibah dan dana bantuan keuangan.

Pelatihan yang dibahas dalam penelitian ini adalah pelatihan yang dilaksanakan oleh DPPKAD. Pelatihan adalah usaha untuk memperbaiki perfomansi pekerja pada suatu pekerjaan yang sedang menjadi tanggung jawabnya atau satu pekerjaan yang ada kaitannya dengan pekerjaannya (Gomes, 2003:197).

Lingkungan kerja merupakan salah satu faktor yang mempengaruhi kinerja pegawai. Kondisi lingkungan kerja dikatakan baik atau sesuai apabila manusia dapat melaksanakan kegiatan secara optimal, sehat, dan nyaman (Sedarmayanti, 2003:12).

Dalam penelitian Ana (2012), salah satu faktor yang dianggap penting bagi peningkatan kinerja yaitu adanya motivasi. Motivasi kerja adalah jiwa pendorong yang kuat bagi manusia untuk melakukan suatu pekerjaan yang berkaitan dengan tujuan dan kebutuhan yang ingin dicapainya. Pentingnya motivasi kerja bagi perusahaan yaitu sebagai faktor pendorong kinerja karyawan. Setiap aktivitas yang dilakukan seseorang pasti memiliki faktor yang mendorong aktivitas tersebut.

Dengan memperlakukan karyawan sebagai aset, secara otomatis ada peningkatan individual capacity, organizational competitive, employee engagement, dan peningkatan kinerja (Wijanarko, 2012:3). Menurut penelitian Raymond (2010), kinerja karyawan merupakan hal penting dalam meningkatkan produktivitas karyawan tersebut. Dalam meningkatkan kinerja karyawan, perusahaan harus dapat mengetahui faktor-faktor yang dapat mempengaruhi kinerja. Faktor-faktor yang dimaksud adalah pelatihan dan motivasi terhadap karyawan. Untuk memecahkan masalah terkait dengan peningkatan kinerja karyawan, ada beberapa kemungkinan yang dapat dilakukan oleh perusahaan, antara lain melalui pemberian motivasi dan pelatihan kerja.

Mengacu pada latar belakang dan rumusan masalah tersebut, maka tujuan dari penelitan ini adalah untuk memperoleh bukti empiris dan mengkaji pengaruh kompensasi, motivasi, pelatihan, dan lingkungan kerja terhadap kinerja pegawai

\section{TINJAUAN PUSTAKA}

\section{Kinerja Pegawai}

Setiap manusia mempunyai potensi untuk bertindak dalam berbagai bentuk aktivitas. Kemampuan bertindak itu dapat diperoleh dari manusia, baik secara alami atau dipelajari. Walaupun manusia mempunyai potensi untuk berperilaku tertentu, tetapi perilaku ini hanya diterapkan pada saatsaat tertentu saja. Potensi untuk berperilaku tertentu itu disebut kinerja (performance ability).

Secara etimologi, kinerja berasal dari kata prestasi kerja. Mangkunegara (2005:67) menyatakan bahwa kinerja berasal dari kata job perfomance atau actual perfomance (prestasi kerja atau prestasi sesungguhnya yang dicapai seseorang). Kinerja adalah hasil kerja secara kualitas dan kuantitas yang dicapai oleh seorang pegawai dalam melaksanakan tugasnya sesuai dengan tanggung jawab yang diberikan kepadanya. Pada umumnya kinerja dibedakan menjadi dua, yaitu kinerja individu dan kinerja organisasi. Kinerja individu adalah hasil kerja karyawan baik dari segi kualitas maupun kuantitas berdasarkan standar kerja yang 
telah ditentukan, sedangkan kinerja organisasi adalah gabungan dari kinerja individu dengan kinerja kelompok.

Handoko (2000:135) mengemukakan bahwa kinerja pada dasarnya adalah kegiatan dan hasil yang dapat dicapai atau dilanjutkan seseorang atau sekelompok orang di dalam pelaksanakan tugas dan pekerjaan yang baik. Pencapaian sasaran atau standar kerja yang telah diterapkan dapat melebihi standar yamg telah ditentukan oleh organisasi pada periode tertentu.

\section{Kompensasi}

Kompensasi didefinisikan oleh Simamora (2004:541) merupakan istilah luas berkaitan dengan imbalan-imbalan finansial (financial reward) yang diterima oleh orang-orang melalui hubungan kepegawaian mereka dengan sebuah organisasi. Menurut Rivai (2004:357), kompensasi merupakan sesuatu yang diterima pegawai sebagai pengganti kontribusi jasa mereka pada perusahaan. Tujuan pemberian kompensasi menurut Rivai (2004:359) adalah untuk membantu perusahaan dan menjamin terciptanya keadilan internal dan eksternal.

Jackson dan Mathis (2002:118) berpendapat bahwa pada dasarnya kompensasi dapat dikelompokkan dalam dua kelompok, yaitu kompensasi langsung dan kompensasi tidak langsung. Kompensasi langsung adalah berupa gaji pokok dan gaji variabel, sedangkan kompensasi tidak langsung berupa tunjangan.

Menurut Hasibuan (2003:122) asas kompensasi meliputi adil dan layak/wajar. Adil berkaitan dengan jabatan, yaitu bahwa semua pegawai di semua jenjang manajemen harus mendapatkannya, sedangkan layak/wajar berkaian dengan besar/kecilnya imbalan yang diterimakan kepada pegawai dengan mempertimbangkan faktor-faktor tertentu, seperti posisi/jabatan, lama pengabdian, tingkat pendidikan, tingkat resiko dan kesulitan tugas.

\section{Motivasi}

Kebutuhan seseorang merupakan dasar untuk model motivasi. Kebutuhan adalah kekurangan yang dirasakan oleh seseorang pada saat tertentu dan menimbulkan tegangan serta menyebabkan timbulnya keinginan. Karyawan akan berusaha untuk menutupi kekurangannya dengan melakukan suatu aktivitas yang lebih baik dalam melaksanakan pekerjaannya. Dengan melakukan aktivitas yang lebih banyak dan baik, karyawan akan memperoleh hasil yang lebih baik pula. Keinginan yang timbul dalam diri karyawan dapat berasal dari dalam diri sendiri maupun berasal dari luar dirinya, baik yang berasal dari lingkungan kerja maupun dari luar lingkungan kerjanya. Motivasi bukanlah merupakan sesuatu yang berdiri sendiri, melainkan ada beberapa faktor yang mempengaruhinya. Arep (2003:51) menjelaskan ada beberapa faktor motivasi yang dirangkum dalam enam faktor secara garis besar, yaitu faktor kebutuhan manusia, kompensasi, komunikasi, kepemimpinan, dan faktor pelatihan.

\section{Pelatihan}

Pelatihan adalah proses secara sistematis mengubah tingkah laku pegawai untuk mencapai tujuan organisasi. Pelatihan memiliki orientasi saat ini dan membantu pegawai untuk mencapai keahlian dan kemampuan tertentu agar berhasil dalam melaksanakan pekerjaannya.

Penelitian Kusmayadi (2008) mendenifisikan perencanaan strategi sebagai suatu proses manajemen yang sistematis yang dapat diartikan sebagai suatu proses pengambilan keputusan atas program-program yang akan dilaksanakan oleh organisasi dan perkiraan sumber daya yang akan dialokasikan dalam setiap program selama beberapa tahun ke depan. 
Keberhasilan organisasi dapat dicapai apabila terdapat kombinasi perencanaan strategis yang baik dengan pelaksanaan strategi yang baik pula.

\section{Lingkungan Kerja}

Lingkungan kerja adalah tempat di mana pegawai melakukan aktivitas setiap harinya. Lingkungan kerja yang kondusif memberikan rasa aman dan memungkinkan pegawai untuk dapat bekerja optimal. Jika pegawai menyenangi lingkungan kerja di mana dia bekerja, maka ia akan betah di tempat kerjanya dengan melakukan aktivitasnya, sehingga waktu kerja dapat dipergunakan secara efektif. Lingkungan kerja yang ada di sekitar pegawai pada saat bekerja baik berupa fisik atau non fisik, langsung maupun tidak langsung, dapat mempengaruhi dirinya dan pekerjaannya dalam bekerja. Pegawai yang berada pada lingkungan kerja yang baik akan merasa nyaman dan optimal dalam menyelesaikan tugasnya.

Lingkungan kerja adalah segala sesuatu yang ada di sekitar para pekerja yang dapat mempengaruhi dirinya dalam menjalankan tugas-tugas yang diembankan. Tanpa adanya lingkungan kerja yang memadai di dalam suatu perusahaan, maka tingkat produktivitas perusahaan pada umumnya akan sulit untuk berada pada tingkat level yang tinggi. Lingkungan kerja yang baik akan membawa dampak yang baik bagi para pekerjanya, demikian pula sebaliknya, apabila lingkungan kerja buruk, maka tidak menutup kemungkinan akan berdampak buruk juga kepada para karyawan. Semua aspek yang dibutuhkan dalam lingkungan kerja haruslah ada, sebab hal ini akan menentukan bagaimana pegawai dapat bekerja secara maksimal

\section{METODE PENELITIAN}

Populasi dalam penelitian ini adalah seluruh pegawai DPPKAD Jawa Tengah. Populasi mengacu pada generalisasi yang terdiri atas obyek atau subyek yang mempunyai kualitas dan karakteristik tertentu yang ditetapkan oleh peneliti untuk dipelajari dan kemudian ditarik simpulannya (Sugiyono, 2010:115). Adapun sampel dalam penelitian ini adalah 50 orang pegawai pada DPPKAD Jawa Tengah yang diambil dengan metode convenience sampling.

Data primer dikumpulkan menggunakan metode survei, yaitu metode penelitian yang dilakukan melalui pengambilan sampel dari suatu populasi dengan menggunakan kuesioner sebagai alat pengumpulan data yang utama, yaitu sejumlah pertanyaan tertulis yang digunakan untuk memperoleh informasi dari responden mengenai pribadi, sikap, dan pendapatnya terhadap beberapa variabel yang menjadi topik penelitian (Indriantoro dan Supomo, 2002:152).

\section{Definisi Operasional Variabel}

\section{Variabel Independen}

Variabel independen adalah variabel yang menjelaskan atau memengaruhi variabel lainnya. Adapun variabel independen dalam penelitian ini ada empat, yaitu kompensasi, motivasi, pelatihan, dan lingkungan kerja.

\section{Variabel Dependen}

Variabel dependen merupakan variabel yang dijelaskan atau dipengaruhi oleh variabel independen. Adapun variabel dependen dalam penelitian ini adalah kinerja pegawai.

Sesuai dengan pernyataan tersebut, pengukuran kuesioner pada penelitian ini menggunakan data Likert Scale yang berisi lima tingkat preferensi jawaban dengan pilihan sebagai berikut:

$\mathrm{SS}=$ Sangat Setuju diberi skor 5

$\mathrm{S}=$ Setuju diberi skor 4

$\mathrm{N}=$ Netral diberi skor 3

TS = Tidak Setuju diberi skor 2

STS = Sangat Tidak Setuju diberi skor 1 


\section{Metode Analisis Data}

Uji Instrumen Penelitian

Uji instrumen penelitian dilakukan untuk mengetahui kualitas data penelitian yang terdiri dari uji validitas dan uji reliabilitas.

\section{Uji Validitas}

Uji ini dilakukan untuk mengetahui validitas kuesioner, yaitu sejauh mana tigkat ketetapan dan kecermatan suatu alat ukur dalam melakukan fungsi ukurnya. Pengujian dilakukan menggunakan Pearson Bivariate, dengan kriteria: apabila $r_{\text {hitung }}>r_{\text {tabel}}$, berarti instrumen yang digunakan adalah valid, dan hasil sebaliknya berlaku untuk kondisi yang berkebalikan.

\section{Uji Reliabilitas}

Uji ini digunakan untuk mengetahui apakah jawaban responden yang digunakan dapat dipercaya atau andal sebagai alat ukur variabel. Dalam hal ini digunakan Cronbach's Alpha $(\alpha)$, yang kriterianya: apabila $\alpha$ suatu variabel > 0,60, maka indikator yang digunakan oleh variabel tersebut aalah reliabel, dan hasil sebaliknya untuk kondisi yang berkebalikan.

\section{Uji Asumsi Klasik}

Uji asumsi klasik digunakan untuk mengetahui ada/tidaknya penyimpangan dalam model regresi. Pada uji asumsi klasik terdapat tiga metode pengujian, yaitu:

\section{Uji Normalitas}

Uji ini digunakan untuk mengetahui apakah data yang digunakan berdistribusi normal atau tidak. Data yang baik adalah memiliki distribusi normal. Pengujian dilakukan dengan Uji KolmogorovSmirnov yang kriterianya: apabila nilai signifikansi > 0,05, maka data berdistribusi normal. Hasil sebaliknya untuk kondisi yang berkebalikan.

\section{Uji Multikolinieritas}

Uji ini digunakan untuk menunjukkan apakah ada korelasi di antara variabel independen. Deteksi ada/tidak terjadinya multikolinearitas dapat dilihat pada collinearity statistics, dengan ketentuan: apabila tolerance value masing-masing variabel independen berada di atas 0,1 dan variance inflation factor (VIF) berada di bawah 10, maka tidak terjadi multikolinearitas. Hasil sebaliknya untuk kundisi yang berkebalikan.

\section{Uji Heteroskedastisitas}

Uji ini bertujuan untuk mengetahui apakah dalam model regresi terjadi ketidaksamaan variance dari residual satu pengamatan ke pengamatan lain. Pengujian menggunakan uji Glejser yang mana apabila probabilitas signifikansinya $>0,05$, maka dapat disimpulkan bahwa model regresi tidak mengandung adanya heteroskedastisitas (Ghozali, 2011:139-142).

\section{Uji Hipotesis}

\section{Regresi Linier Berganda}

Regresi linier berganda digunakan untuk melihat pengaruh antara kompensasi, motivasi, pelatihan, dan lingkungan kerja terhadap kinerja pegawai. Dalam penelitian ini model yang digunakan adalah dengan formula:

$$
\mathrm{KP}=\mathrm{a}+\mathrm{b} 1 \mathrm{KO}+\mathrm{b} 2 \mathrm{MO}+\mathrm{b} 3 \mathrm{PL}+\mathrm{b} 4 \mathrm{LK}+\mathrm{e}
$$

Keterangan:

$$
\begin{aligned}
& \mathrm{KP}=\text { variabel kinerja pegawai } \\
& \mathrm{a}=\text { konstanta } \\
& \mathrm{b}_{1-4}=\text { koefisien regresi } \\
& \mathrm{KO}=\text { variabel kompensasi } \\
& \mathrm{MO}=\text { variabel motivasi kerja } \\
& \mathrm{PL}=\text { variabel pelatihan } \\
& \mathrm{LK}=\text { variabel lingkungan kerja } \\
& \mathrm{e} \quad=\text { faktor pengganggu }(\text { error })
\end{aligned}
$$

\section{Uji t}

Pengujian koefisien regresi parsial (uji t) digunakan untuk mengetahui apakah secara individu variabel independen 
mempunyai pengaruh secara signifikan terhadap variabel dependen, dengan asumsi variabel lainya konstan. Uji $t$ dilakukan dengan membandingkan antara $t_{\text {hitung }}$ dan $t_{\text {tabel. }}$. Kriterianya adalah, apabila nilai $t_{\text {hitung }}>t_{\text {tabel }}$, maka dapat disimpulkan bahwa variabel independen berpengaruh terhadap variabel dependen. Sebaliknya, apabila $t_{\text {hitung }}<t_{\text {tabel}}$, berarti variabel independen tidak berpengaruh terhadap variabel dependen (Ghozali, 2011:99).

\section{Uji F}

Uji-F digunakan untuk melihat hubungan antara variabel bebas terhadap variabel terikat secara simultan, yaitu dengan melihat nilai signifikansi dan/atau membandingkan antara $F_{\text {hitung }}$ dan $F_{\text {tabel }}$. Uji ini juga dimaksudkan untuk mengetahui kelayakan model regresi yang digunakan (goodness of fit). Adapun kriterianya adalah, apabila $F_{\text {hitung }}<$ Ftabel, maka model regresi layak digunakan, sedangkan hasil sebaliknya untuk kondisi yang berkebalikan.

\section{Uji Koefisien Determinasi $\left(\mathbf{R}^{\mathbf{2}}\right)$}

Uji ini dilakukan untuk mengetahui seberapa besar pengaruh variabel independen terhadap naik/turunnya variabel dependen. Dalam persamaan regresi yang menggunakan lebih dari satu variabel independen, maka nilai $R^{2}$ yang tepat digunakan untuk menjelaskan persamaan regresi adalah koefisien determinasi yang disesuaikan (Adjusted$R^{2}$ ), karena telah memperhitungkan jumlah variabel independen dalam suatu model regresi (Ghozali, 2005:108).

\section{HASIL PENELITIAN}

Berdasarkan uji validitas dihasilkan bahwa semua instrumen dari variabel independen (kompensasi, motivasi, pelatihan, dan lingkungan kerja) menunjukkan nilai $r_{\text {hitung }}$ $>r_{\text {tabel }}$ dan variabel dependen (kinerja pegawai) menunjukkan $r_{\text {hitung }}>r_{\text {tabel }}$ juga. Hal ini mengindikasikan bahwa instrumen dari semua variabel tersebut adalah valid.
Dari uji realiabilitas didapatkan semua instrumen variabel independen menunjukkan nilai Cronbach $\alpha$ sebesar $0,70(>0,60)$, sehingga dapat disebutkan bahwa instrumen yang digunakan dalam penelitian ini adalah reliabel.

Dari uji normalitas diperoleh nilai signifikansi $0.134(>0,05)$, sehingga dapat dinyatakan bahwa data terdistribusi normal.

Pada hasil uji multikolinearitas menunjukkan nilai VIF untuk kompensasi 6,914 ; motivasi 1,829 ; pelatihan 1,584 ; dan lingkungan kerja 7,957. Oleh karena nilainya < 10, maka dapat disebutkan bahwa antar variabel independen dalam penelitian ini tidak terjadi multikolinearitas.

Dari uji heteroskedastisitas menemukan angka probabilitas signifikansi variabel kompensasi sebesar 0,271; motivasi 0,195; pelatihan 0,631; dan lingkungan kerja 0,447 . Oleh karena nilainya $>0,05$, maka dapat dikatakan bahwa semua variabel tersebut tidak terjadi masalah heteroskedastisitas.

Berdasarkan tabel Anova diperoleh nilai signifikansi $0,000(<0,05)$, sehingga dapat dikatakan bahwa semua variabel independen (secara bersama-sama) mempengaruhi variabel dependen. Hal ini mengindikasikan juga bahwa model yang digunakan dalam penelitian ini adalah layak (fit of goodness).

Berdasarkan hasil uji koefisien determinasi diperoleh nilai adjusted $R^{2}$ sebesar 0,575. Hal ini berarti bahwa variabel kompensasi, motivasi, pelatihan, dan lingkungan kerja mempengaruhi variabel kinerja pegawai sebesar 57,5\%, sedangkan sisanya $(42,5 \%)$ dipengaruhi oleh variabel lain di luar model penelitian. 
Tabel 1

Hasil Analisis Regresi

\begin{tabular}{|c|c|c|c|c|c|}
\hline \multirow[t]{2}{*}{ Model } & \multicolumn{2}{|c|}{$\begin{array}{l}\text { Unstandardize } \\
\text { d Coefficients }\end{array}$} & \multirow{2}{*}{$\begin{array}{c}\begin{array}{l}\text { Standardized } \\
\text { Coefficients }\end{array} \\
\text { Beta }\end{array}$} & \multirow[t]{2}{*}{$t$} & \multirow[t]{2}{*}{ Sig. } \\
\hline & B & \begin{tabular}{|l} 
Std. \\
Error
\end{tabular} & & & \\
\hline (Constant) & 6,510 & 1,668 & & 3,904 & ,000 \\
\hline $\begin{array}{l}\text { Kompensasi } \\
(\mathrm{KO})\end{array}$ & , 167 & ,124 & ,236 & 1,340 & , 184 \\
\hline $\begin{array}{l}\text { Motivasi } \\
\text { (MO) }\end{array}$ &,- 090 & ,064 &,- 127 & $-1,404$ & 164 \\
\hline Pelatihan (PL) & ,518 & ,076 &, 572 & 6,795 & ,000 \\
\hline $\begin{array}{l}\text { Lingkungan } \\
\text { kerja (LK) }\end{array}$ & ,118 & ,153 & , 146 & ,773 & 441, \\
\hline
\end{tabular}

\section{SIMPULAN}

Dari hasil analisis data diperoleh simpulan bahwa hanya pelatihan yang berpengaruh (secara statistik) signifikan terhadap kinerja pegawai, sedangkan kompensasi, motivasi, dan lingkungan kerja berpengaruh (secara statistik) tidak signifikan. Simpulan ini didasarkan pada nilai signifikansi untuk variabel pelatihan $<0,05$, sedangkan nilai signifikansi variabel kompensasi, motivasi, dan lingkungan kerja $>0,05$. Dapat juga dilihat dari nilai $t$, yang mana untuk variabel pelatihan $t_{\text {hitung }}>t_{\text {tabel}}$, sedangkan variabel kompensasi, motivasi, dan lingkungan kerja $t_{\text {hitung }}<t_{\text {tabel. }}$.

\section{DAFTAR PUSTAKA}

Agusta, Sutanto, 2012. "Pengaruh Pelatihan dan Motivasi kerja terhadap kinerja karyawan CV HARAGON Surabaya." Jurnal Ekonomi. Universitas Kristen Petra, Surabaya.

Ardana, I Komang, Ni Wayan Mujiati, I Wayan Mudiartha Utama, 2012. Manajemen Sumber Daya Manusia. Edisi Pertama. Yogyakarta: Graha Ilmu.

Danang, Artinto Saputra, 2012. "Pengaruh Gaya Kepemimpinan, Komunikasi Organisasi, dan Motivasi Terhadap Kinerja Tenaga Akademik pada
Akademi Keperawatan Rumah Sakit Pusat Angkatan Darat (RSPAD) Gatot Soebroto Jakarta." Jurnal Falkutas Ekonomi. Universitas Gunadarma. Jakarta.

Ekaningsih, et, al. 2012. "Pengaruh Motivasi Kerja terhadap kinerja dengan persepsi Lingkungan kerja sebagai variabel pemoderasi pada satuan polisi pamong praja kota Surakarta." Jurnal Akuntansi. Fakultas Ekonomi STIE Bulungan, Tarakan.

Halim, et, al. 2012. "Analisis Pengaruh Motivasi dan Lingkungan kerja terhadap Kinerja Karyawan pada PT Sinar Galesong Pratama Makasar." Skripsi. Fakultas Ekonomi dan Bisnis, Universitas Hassanuddin, Makasar.

Marjani, 2005. "Hubungan Motivasi Kerja dengan Kinerja Pegawai pada Unit Pelaksanaan Teknis Dinas Perhubungan Propinsi DKI Jakarta." Skripsi. Institut Pertanian Bogor.

Marpaung, Iga Mawarni, Djamhur Hamid, dan Mohammad Iqbal, 2015. "Pengaruh Motivasi dan Disiplin Kerja Terhadap Kinerja Karyawan (Studi Pada Karyawan Rumah Sakit Reksa Waluya Mojokerto)." Jurnal Ekonomi. Fakultas Ilmu Administrasi . Universitas Brawijaya. Malang.

Mathis Robert L \& Jackson John H, 2002. Manajemen Sumber Daya Manusia. Jakarta: Salemba Empat.

Mallisa, et, al, 2014. "Pengaruh Pelatihan, Lingkungan kerja dan Motivasi kerja terhadap kinerja pegawai pada Dinas Pendapatan Pengelolaan Keuangan dan Aset Daerah Kota Tanjungpinang." Jurnal Akuntansi. Fakultas 
Ekonomi, Universitas Maritim Raja Ali Haji.

Megawati, Erlly, 2012. "Pengaruh Kompensasi Financial, Gaya Kepemimpnan, dan Motivasi Kerja terhadap Kinerja Karyawan pada PT Asia Marco di Karanganyar." Skripsi. Fakultas Ekonomi, UMS, tidak dipublikasikan.

Nugrahanto, Faizal Dwi, 2015. "Pengaruh Kepemimpinan dan Lingkungan Kerja Terhadap Kinerja Karyawan Rumah Sakit Ortopedi Prof. Dr. R. Soeharso Surakarta." Skripsi. Fakultas Ekonomi dan Bisnis, Universitas Muhammadiyah Surakarta.

Reza, Regina, 2010. "Pengaruh Gaya Kepemimpinan, Motivasi dan Disiplin Kerja terhadap kinerja karyawan PT. Sinar Santosa Perkasa Banjarnegara." Skripsi. Fakultas Ekonomi , Universitas Diponegoro Semarang.

Rivai, Veithzal, 2004. Manajemen Sumber Daya Manusia Untuk Perusahaan. Edisi Pertama. Jakarta: PT Raja Grafindo Persada.

Simamora, Henry, 2004. Manajemen Sumber Daya Manusia. Yogyakarta: SIE YKPN.

Suadi, Arief, Ph.D. 1995. Sistem Pengendalian Manajemen. Cetakan Pertama. Edisi Pertama. Yogyakarta: BPFE

Sugiyono, 2010. Metode Penelitian Kuantitatif Kualitatif dan $R \& D$. Bandung: Alfabeta.

Suwondo, Diah Indriani dan Sutanto, Eddy Madiono. 2015. "Hubungan Lingkungan Kerja, Disiplin Kerja, dan Kinerja Karyawan." Jurnal Manajemen dan Bisnis. Vol. 17 No. 2 September 2015. Universitas Kristen Petra Surabaya.
Sari, Dyan R, 2012. "Pengaruh Budaya Organisasi dan Motivasi Kerja terhadap Kinerja Karyawan Bagian Marketing Koperasi Jasa Keuangan Syari'ah Baitul Maal Wat Tamwill." Skripsi. Fakultas Keguruan dan ilmu pendidikan, Universitas Sebelas Maret Surakarta.

Sugiyono, 2010. "Metode Penelitian Bisnis." Cetakan Ke-15. Bandung: CV Alfabeta.

Suryoadi, et. al, 2012. "Pengaruh Pelatihan dan kepuasan Kompensasi terhadap Kinerja Karyawan pada PT Bank Muamalat Indonesia Cabang Semarang." Skripsi. Fakultas Ekonomika dan Bisnis, Universitas Diponegoro Semarang.

Wahyuningtyas, et al, 2013. "Lingkungan Kerja dan Kompensasi terhadap Kinerja Karyawan." Skripsi. Fakultas Ekonomika dan Bisnis, Universitas Diponegoro Semarang 